\title{
REVISED Case Report: Microsurgical excision of grade 5 cerebral
}

\section{AVM [version 2; peer review: 1 approved, 2 approved with}

\section{reservations]}

\author{
Sunil Munakomi (D), Binod Bhattarai, Iype Cherian (iD)
}

College of Medical Sciences, Bharatpur, Chitwan, 44207, Nepal

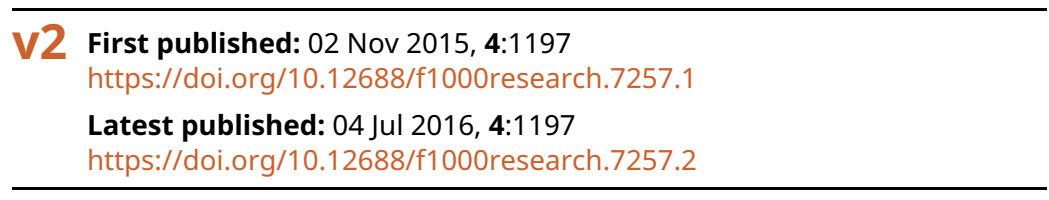

\section{Abstract}

In this case report, we discuss the microsurgical management of a Spetzler-Martin grade 5 arteriovenous malformation (AVM) in a young boy who presented with a hemorrhagic episode and had a high calculated risk of rebleeding. We also outline the rationale for choosing the management option.

Keywords

arteriovenous malformation, AVM, grading, management

\begin{tabular}{|c|c|c|c|}
\hline \multicolumn{4}{|c|}{ Open Peer Review } \\
\hline \multicolumn{4}{|c|}{ Approval Status ? ? } \\
\hline & 1 & 2 & 3 \\
\hline \multicolumn{4}{|l|}{ version 2} \\
\hline & $?$ & $?$ & $\checkmark$ \\
\hline 04 Jul 2016 & view & view & view \\
\hline & m & a & \\
\hline version 1 & $?$ & X & \\
\hline 02 Nov 2015 & view & view & \\
\hline
\end{tabular}

1. Kenichiro Kikuta, University of Fukui, Fukui, Japan

2. Sunil Kumar Singh, King George's Medical University, Lucknow, India

3. Guo-Yi Gao, Shanghai Jiao Tong University, Shanghai, China

Any reports and responses or comments on the article can be found at the end of the article. 
Corresponding author: Sunil Munakomi (sunilmunakomi@gmail.com)

Competing interests: The authors declared no conflict of interest.

Grant information: The author(s) declared that no grants were involved in supporting this work.

Copyright: @ 2016 Munakomi S et al. This is an open access article distributed under the terms of the Creative Commons Attribution License, which permits unrestricted use, distribution, and reproduction in any medium, provided the original work is properly cited. Data associated with the article are available under the terms of the Creative Commons Zero "No rights reserved" data waiver (CC0 1.0 Public domain dedication).

How to cite this article: Munakomi S, Bhattarai B and Cherian I. Case Report: Microsurgical excision of grade 5 cerebral AVM [version 2; peer review: 1 approved, 2 approved with reservations] F1000Research 2016, 4:1197

https://doi.org/10.12688/f1000research.7257.2

First published: 02 Nov 2015, 4:1197 https://doi.org/10.12688/f1000research.7257.1 


\section{REVISED Amendments from Version 1}

In this revised version, we have included two new figures

1. Depicting size of the AVM nidus during early and late phase of preoperative angiography.

2. Postoperative angiography revealing complete excision of the nidus with no remaining feeders

We hope these will have significant additive value in the context of our paper.

\section{See referee reports}

\section{Introduction}

As of now, many tenets exist regarding management of high grade cerebral arterio-venous malformation (AVM) management, making a rigid algorithm impossible to create. In experienced hands, microsurgery proved to have better results, compared to other treatments ${ }^{1,2}$. Herein, we report a microsurgical management of a grade 5 arteriovenous malformation (AVM) in a young patient with a high predicted risk for rebleeding.

\section{Case report}

A 22-year-old Brahmin male from Khaireni, a remote village in Nepal, presented to our emergency room with a sudden-onset severe headaches and left-sided weakness over the last 24 hours. Physical examination revealed a Glasgow coma scale (GCS) of $14 / 15$ with left-sided hemiparesis of $3+/ 5$ (Medical research council grading). Medical history was significant for a few episodes of paroxysmal headaches since last couple of years, which improved after taking $500 \mathrm{mg}$ Paracetamol tablet on an 'as needed' basis. The frequency and intensity of the headache had worsened in the last few months. There was no significant family history. An urgent head computerized tomogram (CT) revealed evidence of a hyperdense lesion with peripheral stippled calcification on the right side in the territory of posterior limb of internal capsule and the retro-thalamic region (Figure 1). There was also coating of vessel along the middle cerebral artery (MCA) territory (Figure 2) and hyperdensity along

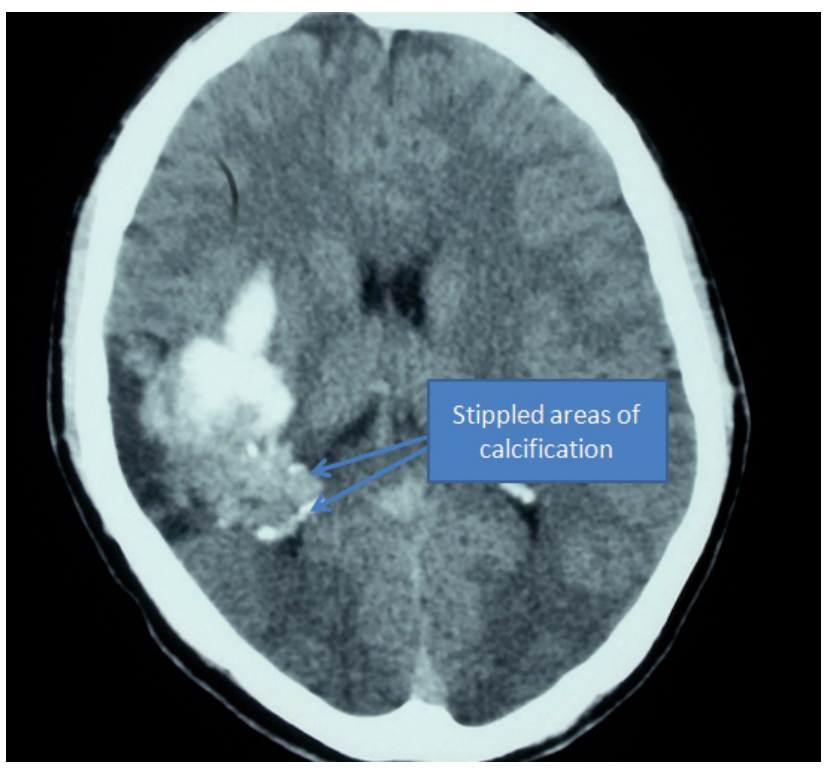

Figure 1. CT showing presence of hyperdense lesion in the right parietal region with stippled calcification on the periphery.

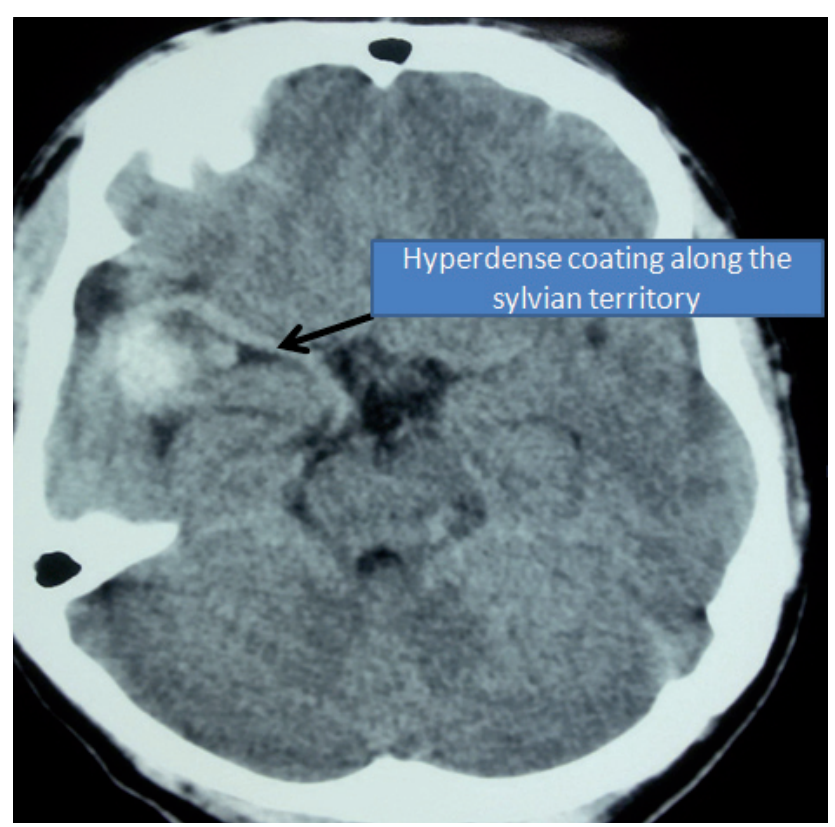

Figure 2. CT showing presence of coating along the MCA territory. 
the deep venous territory. A four-vessel diagnostic carotid angiography revealed Grade 5 Spetzler-Martin AVM in the right sub corticol region with feeders from lenticulostiates of the middle cerebral artery (Figure 3). Drainage was to the deep draining veins and also to the superior sagittal sinus (Figure 4).

Multiple factors such as young age at presentation, the fact that the lesion had bled, presentation of patient with deficits associated with the lesion on the non-dominant side, presence of deep venous drainage and intra-nidal aneurysm led to a high calculated risk for rebleeding in the patient. We therefore decided on surgical management, despite the high grade of the lesion. After explanation of the risks of the treatment and role of adjuvants in the form of radiosurgery and embolisation the patient was taken up for microsurgical excision. Since the facility of radiosurgery is not available in the country, we only had the option of embolisation of the feeders prior

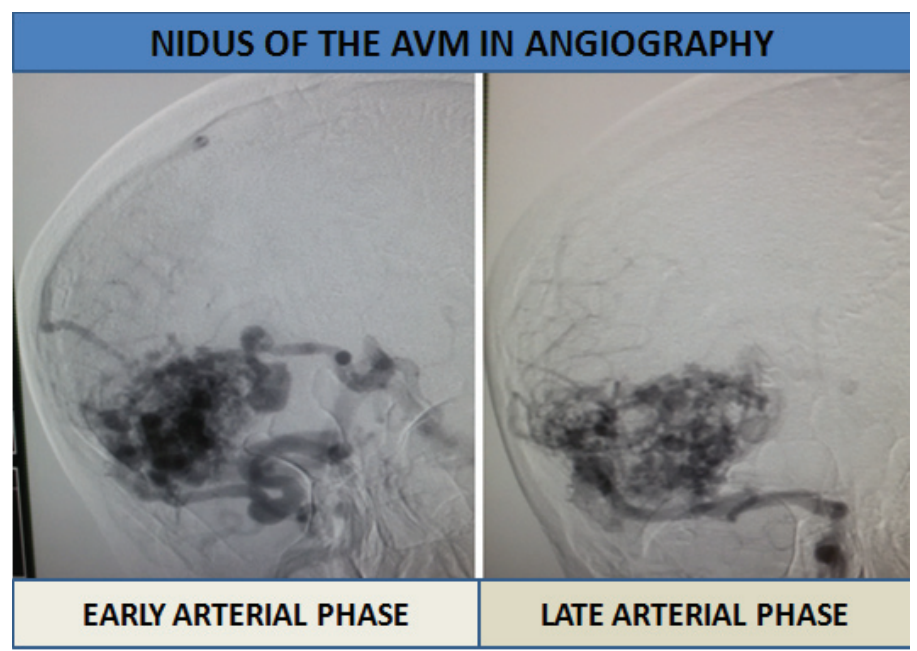

Figure 3. Angiogram showing the nidus of the AVM during angiography.

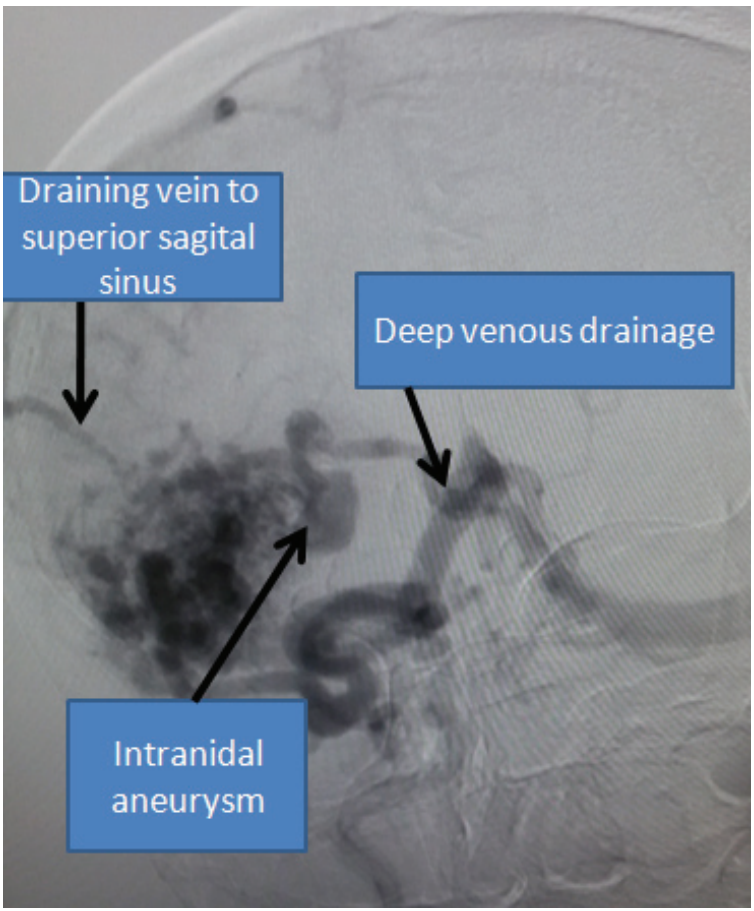

Figure 4. Angiogram showing the major deep draining vein and a single vein to the superior sagittal sinus. 
to the surgical excision of the lesion. However, since the lesion had only low velocity feeders from the lenticulostriate vessels, we opted for direct microsurgical management. After a liberal craniotomy, basal cisterns were opened to gain access to the M1 branch of the MCA. We identified the major deep draining vein that was looping over the MCA bifurcation with the help of Indocyanine Green (ICG) venography. We placed a temporary clip on M1, then made a minimal corticostomy over the parietal cortex and continued our dissection over the gliotic tissue surrounding the AVM taking care of the minimal bleeders with the help of bipolar cauterization and avoiding inadvertent entry to the nidus. Lastly a clip was applied to the draining vein after completely dissecting the AVM nidus. The lesion was finally excised (Figure 5). Complete hemostasis was confirmed.

Postoperatively his blood pressure was rigorously monitored so as not to overshoot the mean arterial pressure above $100 \mathrm{~mm}$ of mercury so as to prevent breakthrough perfusion rebleeding. Patient was started on Sodium Valproate (1 gm stat followed by $300 \mathrm{mg}$ IV 8 hourly) and Nimodipine (60 mg 4 hourly via nasogastric tube) for seizure and vasospasm prophylaxis, respectively. Repeat head CT scan the following morning revealed no cavity hematoma or any evidence of vasospasm (Figure 6). Patient was extubated uneventfully. He had hemiparesis of $3+$ in upper limbs and 3 in lower limbs. Patient was started on physiotherapy and finally discharged home on the $7^{\mathrm{TH}}$ post-operative day after removal of sutures. Patient came for follow-up 2 weeks later walking on his own with left upper limb weakness of grade $3+/ 5$. The Nimodipine was tapered off in the subsequent three weeks. The patient was advised to continue Na Valproate $300 \mathrm{mg}$ orally three times a day for at least a year. Post operative angiography revealed complete excision of the AVM with no remaining feeders (Figure 7). The patient followed up in the outpatient clinic 6 months later with minimal pronator drift on the left arm and grade 2 spasticity on his left leg.

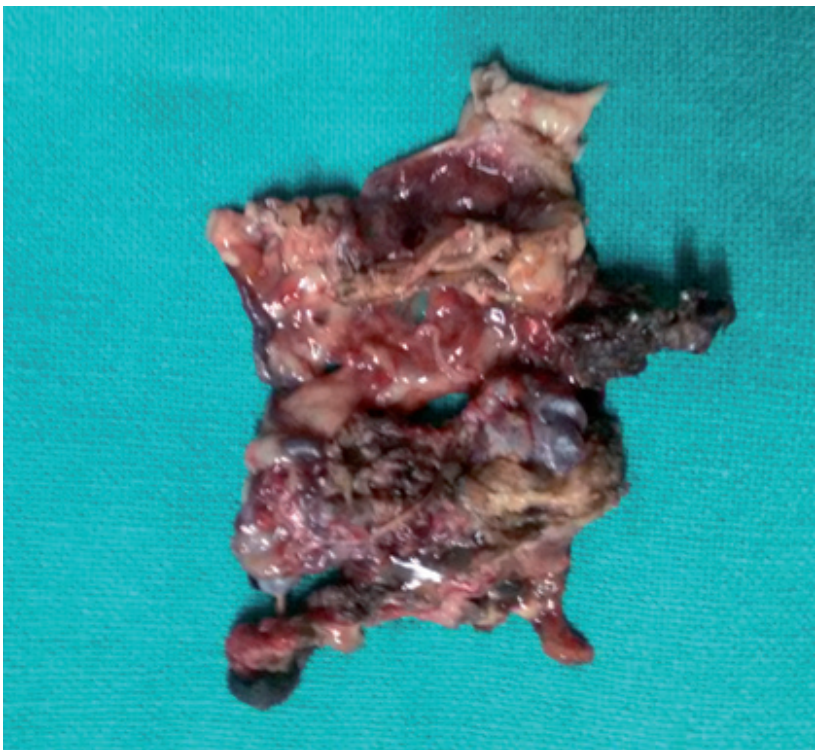

Figure 5. Excised AVM nidus.

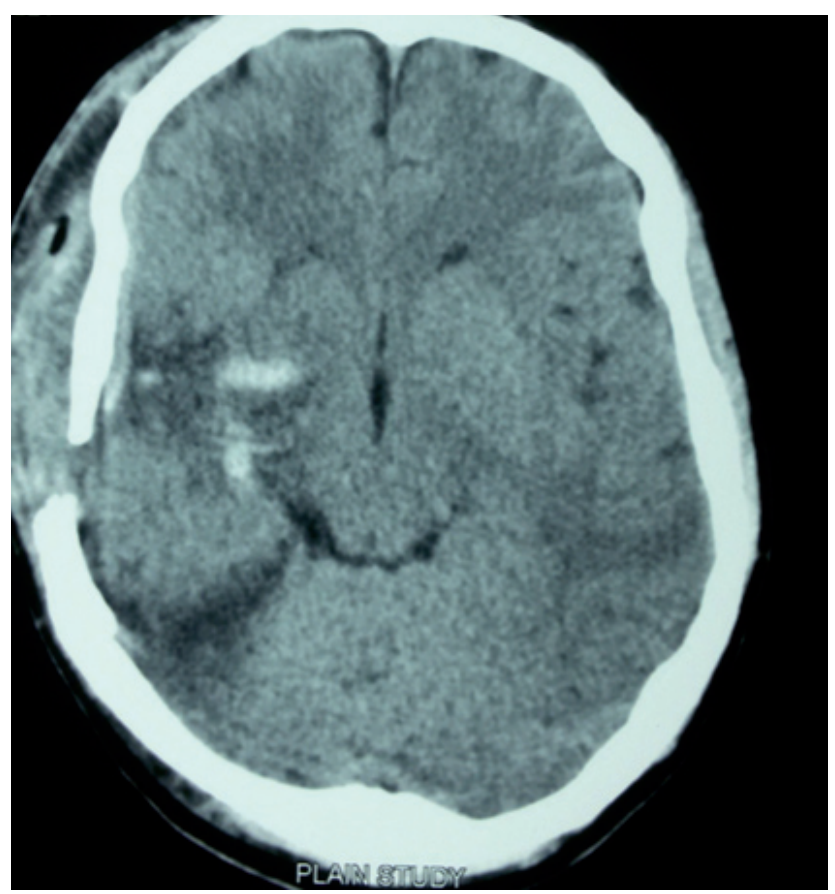

Figure 6. Post-operative scan with no haemorrhage or the evidence of vasospasm. 


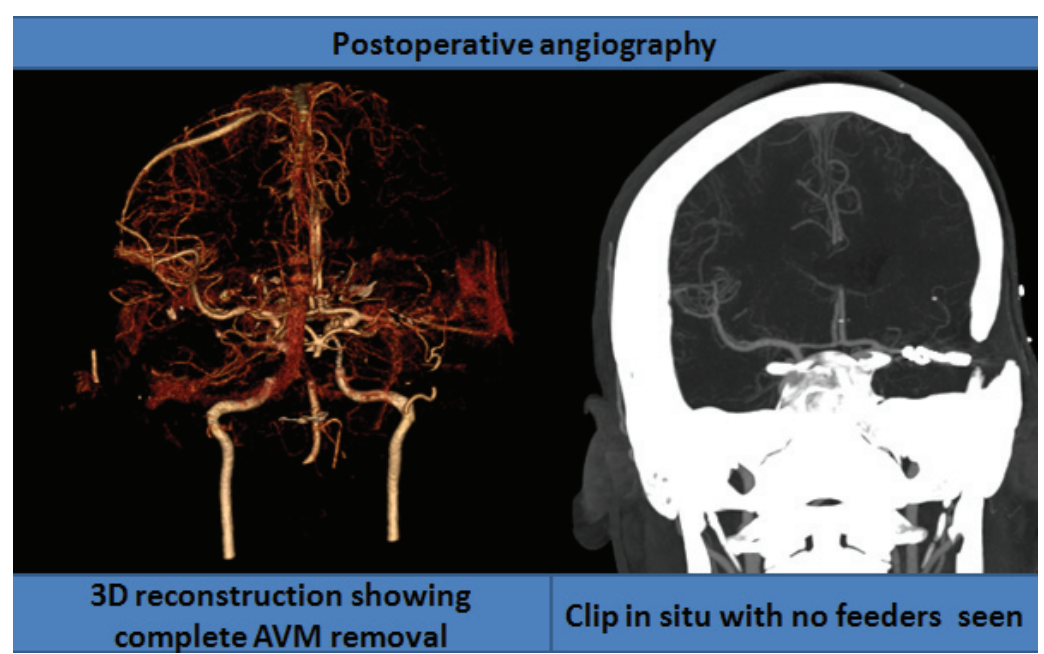

Figure 7. Post operative angiography revealing complete excision of the AVM with no residual feeders left.

\section{Discussion}

Bleeding within the AVM is considered a significant predictor of rebleeding. Other important factors moderating risk of rebleeding include deep venous drainage ${ }^{3}$. Studies have verified that the risk of rebleeding under these circumstances is as high as $34.4 \%$ compared to just $0.9 \%$ per year in patients without these risk factors ${ }^{4,5}$. Another important factor to be considered while calculating the risk of rebleeding is the presence of concurrent aneurysm within the AVM (6.93\% with aneurysm Vs $3.99 \%$ without aneurysm).

Up to $40 \%$ of cases with AVM manifest neurological deficits ${ }^{6}$, mostly attributable to hemorrhage. A minority of only $5 \%$ to $15 \%$ of such deficits are related to factors such as coronary steal phenomenon and venous hypertension ${ }^{7-9}$.

The Spetzler-Martin Scale is used to estimate the risk of surgical resection of an AVM with higher grades being associated with greater surgical morbidity and mortality ${ }^{10}$. Multivariate studies have shown this grading system to reliably predict permanent major morbidity or mortality at the following levels: Grade I (4\%), Grade II (10\%), Grade III (18\%), Grade IV (31\%), and Grade V $(37 \%)^{11}$. This data has been further validated prospectively, and this grading system remains the most widely used among neurosurgeons and neurointerventionalists ${ }^{12}$.

Han et al. reported the management of 73 grade 4 and 5 lesions and found the annual hemorrhage rate for untreated lesions to be only $1.5 \%$ versus $10.4 \%$ for partially treated lesions ${ }^{13}$. Grade IV or $\mathrm{V}$ lesions are only treated in circumstances of progressive neurological deterioration from hemorrhage, vascular steal, or seizure as seen in our case, which had a high risk of rebleeding because of presentation at young age with hemorrhagic episode, large size of the nidus, deep venous drainage pattern and associated aneurysm within the AVM.

There is time-lag of about two years following radiosurgery for complete obliteration of the nidus in the lesion. The risk of hemorrhage in this time period is around $4.8 \%$ per year ${ }^{14}$ which parallels the natural history of the lesion after bleeding. However there is a risk of inadvertent radiation injury to the adjacent eloquent brain are $\mathrm{a}^{15}$ and also a risk of symptomatic radiation necrosis in around $9 \%$ of cases $^{15,16}$.

The main indication for other embolisation options in such a high grade of AVM is in order to downgrade the lesion and to minimise the intraoperative blood loss so as to make the lesion amenable for microsurgical excision, which bears an acceptable complication rate of around just $6.5 \%{ }^{17}$. One study has shown that the deep venous drainage, higher grade of the lesions and the periprocedural hemorrhage are predictors of post procedural complications following the embolisation treatment ${ }^{17}$.

In our case there were only few feeders from the lenticulostriate branches from MCA: not ideal for embolization. Partial embolisation of the lesion will not reduce the risk of hemorrhage to zero ${ }^{3}$. Partial embolisation of the high grade lesions are only justified in few circumstances, such as in vascular steal phenomenon or an AVM with associated aneurysm ${ }^{18}$.

\section{Conclusion}

In a few selected cases who have a high calculated risk of rebleeding, microsurgical excision remains a therapeutic option even for 
a high grade AVM especially in centers with limited resources for intervention and radiosurgery. However, all the patients should be well counseled about the available alternative mode of intervention and the associated risks. The management plan in each patient should be tailored addressing factors such as age of the patient, mode of presentation, grade of the lesion, treatment modalities and expertise availability etc.

\section{Consent}

Written, informed consent was sought and attained from the father of the patient as per medical protocol in Nepal.

\section{Author contributions}

Dr Sunil prepared the manuscript and obtained the pictures. Dr Binod and Dr Cherian revised and confirmed the final manuscript. All authors have seen and agreed to the final content of the manuscript.

\section{Competing interests}

The authors declared no conflict of interest.

\section{Grant information}

The authors declared that no funding was involved in supporting this work.
1. Potts $\mathrm{MB}$, Chang EF, Young $\mathrm{WL}$, et al:: Transsylvian-transinsular approaches to the insula and basal ganglia: operative techniques and results with vascular lesions. Neurosurgery. 2012; 70: 824-834; discussion 834. PubMed Abstract | Publisher Full Text | Free Full Text

2. Potts MB, Young WL, Lawton MT, et al.: Deep arteriovenous malformations in the Basal Ganglia, thalamus, and insula: microsurgical management, techniques, and results. Neurosurgery. 2013; 73: 417-427. PubMed Abstract | Publisher Full Text | Free Full Text

3. de Costa L, Wallace MC, Ter Brugge KG, et al:: The natural history and predictive features of hemorrhage from brain arteriovenous malformations. Stroke. 2009; 40(1): 100-105.

PubMed Abstract | Publisher Full Text

4. Hofmeister C, Stapf C, Hartmann A, et al:: Demographic, morphological, and clinical characteristics of 1289 patients with brain arteriovenous malformation. Stroke. 2000; 31(6): 1307-1310.

PubMed Abstract | Publisher Full Text

5. Pollock BE, Flickinger JC, Lunsford LD, et al.: Factors that predict the bleeding risk of cerebral arteriovenous malformations. Stroke. 1996; 27(1): 1-6. PubMed Abstract | Publisher Full Text

6. The Arteriovenous Malformation Study Group: Arteriovenous malformations of the brain in adults. N Engl J Med. 1999; 340(23): 1812-1818. PubMed Abstract | Publisher Full Text

7. Mast $\mathrm{H}$, Mohr JP, Osipov A, et al: 'Steal' is an unestablished mechanism for the clinical presentation of cerebral arteriovenous malformations. Stroke. 1995 ; 26(7): 1215-1220.

PubMed Abstract | Publisher Full Text

8. Choi $\mathrm{JH}$, Mast $\mathrm{H}$, Sciacca RR, et al: Clinical outcome after first and recurrent hemorrhage in patients with untreated brain arteriovenous malformation. Stroke. 2006; 37(5): 1243-1247.

PubMed Abstract | Publisher Full Text

9. Friedlander RM: Clinical practice. Arteriovenous malformations of the brain N Engl J Med. 2007; 356(26): 2704-2712. PubMed Abstract | Publisher Full Text

10. Spetzler RF, Ponce FA: A 3-tier classification of cerebral arteriovenous malformations. Clinical article. J Neurosurg. 2011; 114(3): 842-9. PubMed Abstract | Publisher Full Text

11. Hamilton MG, Spetzler RF: The prospective application of a grading system for arteriovenous malformations. Neurosurgery. 1994; 34(1): 2-6; discussion 6-7.

PubMed Abstract | Publisher Full Tex

12. Castel JP, Kantor G: Postoperative morbidity and mortality after microsurgical exclusion of cerebral arteriovenous malformations. Current data and analysis of recent literature. Neurochirurgie. 2001; 47(2-3 Pt 2): 369-383. PubMed Abstract

13. Han PP, Ponce FA, Spetzler RF: Intention-to-treat analysis of Spetzler-Martin grades IV and V arteriovenous malformations: natural history and treatment paradigm. J Neurosurg. 2003; 98(1): 3-7. PubMed Abstract | Publisher Full Text

14. Hernesniemi JA, Dashti R, Juvela S, et al:: Natural history of brain arteriovenous malformations: a long-term follow-up study of risk of hemorrhage in 238 patients. Neurosurgery. 2008; 63(5): 823-829. PubMed Abstract | Publisher Full Text

15. Flickinger JC, Lunsford LD, Kondziolka D, et al.: Radiosurgery and brain tolerance: an analysis of neurodiagnostic imaging changes after gamma knife radiosurgery for arteriovenous malformations. Int J Radiat Oncol Biol Phys. 1992; 23(1): 19-26. PubMed Abstract | Publisher Full Text

16. Finitsis S, Anxionnat R, Bracard S, et al:: Symptomatic Radionecrosis after AVM Stereotactic Radiosurgery. Study of 16 Consecutive Patients. Interv Neuroradiol. 2005; 11(1): 25-33. PubMed Abstract | Free Full Text

17. Ledezma CJ, Hoh BL, Carter BS, et al.: Complications of cerebral arteriovenous malformation embolization: multivariate analysis of predictive factors. Neurosurgery. 2006; 58(4): 602-611; discussion 602-11. PubMed Abstract | Publisher Full Text

18. Krings T, Hans FJ, Geibprasert S, et al.: Partial "targeted" embolisation of brain arteriovenous malformations. Eur Radiol. 2010; 20(11): 2723-31. PubMed Abstract | Publisher Full Text | Free Full Tex 


\section{Open Peer Review}

\section{Current Peer Review Status:}

\section{Version 2}

Reviewer Report 28 October 2016

https://doi.org/10.5256/f1000research.9835.r17066

(C) 2016 Gao G. This is an open access peer review report distributed under the terms of the Creative Commons Attribution License, which permits unrestricted use, distribution, and reproduction in any medium, provided the original work is properly cited.

\section{Guo-Yi Gao}

Department of Neurosurgery, Shanghai Jiao Tong University, Shanghai, China

This is a very successful case of surgical removal of high grade AVM which is not ideal for embolism. The experiences of decision making and surgical strategy are both beneficial to the readers.

Competing Interests: No competing interests were disclosed.

I confirm that I have read this submission and believe that I have an appropriate level of expertise to confirm that it is of an acceptable scientific standard.

Reviewer Report 21 September 2016

https://doi.org/10.5256/f1000research.9835.r16467

(C) 2016 Singh S. This is an open access peer review report distributed under the terms of the Creative Commons Attribution License, which permits unrestricted use, distribution, and reproduction in any medium, provided the original work is properly cited.

\section{Sunil Kumar Singh}

Department of Neurosurgery, King George's Medical University, Lucknow, India

I have seen the revised manuscript. I still see that the AVM appears overgraded as the size and eloquence appear doubtful, in absence of measurements.

Competing Interests: No competing interests were disclosed.

I confirm that I have read this submission and believe that I have an appropriate level of expertise to confirm that it is of an acceptable scientific standard, however I have 
significant reservations, as outlined above.

Reviewer Report 31 August 2016

https://doi.org/10.5256/f1000research.9835.r15967

(c) 2016 Kikuta K. This is an open access peer review report distributed under the terms of the Creative Commons Attribution License, which permits unrestricted use, distribution, and reproduction in any medium, provided the original work is properly cited.

\section{Kenichiro Kikuta}

Department of Neurosurgery, University of Fukui, Fukui, Japan

This is an interesting paper but I do not agree that it was grade 5 AVM. The size is probably over $6 \mathrm{~cm}$, and deep drainage can also be confirmed, but it is unclear whether this AVM is located in an eloquent area or not. I think the authors should answer this question before the article is indexed.

Competing Interests: No competing interests were disclosed.

I confirm that I have read this submission and believe that I have an appropriate level of expertise to confirm that it is of an acceptable scientific standard, however I have significant reservations, as outlined above.

\section{Version 1}

Reviewer Report 22 March 2016

\section{https://doi.org/10.5256/f1000research.7819.r12755}

(C) 2016 Singh S. This is an open access peer review report distributed under the terms of the Creative Commons Attribution License, which permits unrestricted use, distribution, and reproduction in any medium, provided the original work is properly cited.

\section{Sunil Kumar Singh}

Department of Neurosurgery, King George's Medical University, Lucknow, India

It is a well written case report and the discussion is precise. Main points for not approving this article are:

1. Grading appears faulty as size of nidus, eloquence and drainage are suspicious on single images. more images might have been helpful. The AVM at best appears to be grade 3 .

2. As such, it would be a routine microsurgical excision of an AVM 
Competing Interests: No competing interests were disclosed.

I confirm that I have read this submission and believe that I have an appropriate level of expertise to state that I do not consider it to be of an acceptable scientific standard, for reasons outlined above.

Reviewer Report 12 November 2015

https://doi.org/10.5256/f1000research.7819.r10999

(c) 2015 Kikuta K. This is an open access peer review report distributed under the terms of the Creative Commons Attribution License, which permits unrestricted use, distribution, and reproduction in any medium, provided the original work is properly cited.

\section{Kenichiro Kikuta}

Department of Neurosurgery, University of Fukui, Fukui, Japan

The authors reported a case of S-M grade 5 AVM successfully treated by microsurgical resection. I have some questions about as below.

1. How did the authors measure the size of AVM. How did they distinguish hematoma from AVM? Was the AVM alone really above $6 \mathrm{~cm}$ in diameter? The authors should show the image such as T2-weighted images of MRI or enhanced CT clearly indicating the size of AVM.

2. Was the AVM really located in the eloquent area? The authors should show the location of nidus clearly. I think not nidus but only hematoma was located in the insult.

3. Magnification of figures 3 and figures 4 was too high. The authors should show angiograms of A-P view and lateral view with less magnification.

4. Why didn't the authors perform preoperative embolization? I think it would be helpful in cases of high-grade AVMs.

Competing Interests: No competing interests were disclosed.

I confirm that I have read this submission and believe that I have an appropriate level of expertise to confirm that it is of an acceptable scientific standard, however I have significant reservations, as outlined above. 
The benefits of publishing with F1000Research:

- Your article is published within days, with no editorial bias

- You can publish traditional articles, null/negative results, case reports, data notes and more

- The peer review process is transparent and collaborative

- Your article is indexed in PubMed after passing peer review

- Dedicated customer support at every stage

For pre-submission enquiries, contact research@f1000.com 